THE EFFECT OF FINANCING RISKS, CAPITAL ADEQUACY LEVEL AND OPERATIONAL EFFICIENCY IN SHARIA BANKING PROFITABILITY

\title{
PENGARUH RISIKO PEMBIAYAAN, TINGKAT KECUKUPAN MODAL DAN EFISIENSI OPERASIONAL TERHADAP PROFITABILITAS BANK SYARIAH
}

\author{
Oleh: \\ Ridwan ${ }^{1)}$, Zamzami ${ }^{2)}$, Yudi ${ }^{3)}$ \\ 1) Alumni Magister Ilmu Akuntansi Pasca Sarjana Universitas Jambi Tahun 2021 bekerja di \\ PT Bank Mandiri, tbk Cab. Pontianak - Indonesia \\ ${ }^{2 \& 3}$ Fakultas Ekonomi dan Bisnis Universitas Jambi - Indonesia \\ Email: $\underline{\text { ridwan047882249@gmail.com }}^{1)}$ zamzam@unja.ac.id $^{2)}$ yudi_fe@unja.ac.id ${ }^{3)}$
}

\begin{abstract}
Obtaining large and high profitability is the expectation of all companies, including the Islamic banking industry in Indonesia in order to maintained company going concern. In effort to achieve the profitability, generally syariah bank's operational activities will be influenced by several factors including the risk of financing managed, the level of capital adequacy owned by the bank and the bank will strive to make operational efficiency as effective as possible. This study aim to see whether the effect of managed financing risk, the level of capital adequacy and operational efficiency on the profitability of Islamic bank. The sample of this study used purposive sampling method which took the Islamic bank financial statement data during 2015 until 2019. This study used t test regression analysis technique and F test (ANOVA). The result of this study showing significant influence on the risk of financing (Financing to Deposit Ratio/FDR), the level of capital adequacy (Capital Adequacy Ratio/CAR) and operational efficiency on the achievement of profitability (Operating Expense to Operatng Income/OEOI) to Islamic banking profitability (Return on Assets/ROA) and there is no significant influence on Non Performing Financing (NPF) in profitability achievement (ROA). The result of this study are in line with some of the results of previous studies.
\end{abstract}

Keywords: Profitability, Return on Assets, Non Performing Financing Ratio. Financing to Deposit Ratio, Capital Adequacy Ratio, Operating Expense to Operational Income.

\begin{abstract}
ABSTRAK
Memperoleh profitabilitas yang besar /tinggi merupakan ekpekstasi seluruh perusahaan termasuk industri perbankan syariah yang ada di Indonesia agar going concern bank terjaga. Dalam usaha mencapai profitabilitas tersebut, umumnya aktivitas operasional bank syairah akan dipengaruhi beberapa faktor diantaranya yaitu risiko pembiayaan yang dikelola, tingkat kecukupan modal yang dimiliki oleh bank dan bank akan berupaya untuk melakukan efisiensi operasional seefektif mungkin. Penelitian ini dilakukan untuk melihat apakah pengaruh dari risiko pembiayaan yang dikelola, tingkat kecukupan modal dan efisiensi operasional terhadap profitabilitas bank syariah. Sampel dalam penelitian ini diipilih dengan menggunakan teknik purposive sampling method yang mengambil data laporan keuangan bank syariah selama periode 2015 sampai 2019. Penelitian ini menggunakan teknik analisis regresi uji $\mathrm{t}$ dan uji $\mathrm{F}$ ( ANOVA). Hasil penelitian ini menunjukan bahwa terdapat pengaruh signifikan pada risiko pembiayaan (Financing to Deposit Ratio /FDR), tingkat kecukupan modal (Capital Adequacy Ratio/CAR) dan efisiensi operasional (Biaya Operasional Pendapatan Operasional/BOPO) terhadap pencapaian profitabilitas bank (Retun on Assests) meski ada yang tidak memberi pengaruh secara signifikan pada risiko pembiayaan (Non Performing Financing/NPF) terhadap profitabilitas (ROA). Hasil penelitian ini sejalan dengan beberapa hasil penelitian terdahulu.
\end{abstract}

Keywords: Profitabilitas, Return on Assets, Non Performing Financing Ratio. Fiancing to Deposit Ratio, Capital Adequacy Ratio, Biaya Operasional Pendapatan Operasional 


\section{PENDAHULUAN}

Perkembangan bank syariah di Indonesia dimulai pada tahun 1980, melalui diskusi-diskusi bertemakan bank Islam sebagai pilar ekonomi Islam sehingga pada tahun 1988 (pakto 88) pemerintah berhasil melakukan liberalisasi sistem perbankan dengan mengeluarkan paket kebijakan deregulasi yang memberi kesempatan yang luas pada bisnis perbankan untuk menunjang pembangunan liberalisasi sistem perbankan. Pada tahun 1990, Majelis Ulama Indonesi (MUI) membentuk kelompok kerja untuk mendirikan Bank Islam di Indonesia dan terealisasi dengan berdirinya bank syariah pertama yaitu PT Bank Muamalat Indonesia (BMI) pada tanggal 1 Nopember 1991 dan mulai beroperasional 1 Mei 1992 dengan landasan hukum pada undang - undang no. 7 tahun 1992 dimana salah satu ayatnya mengatur tentang bank dengan sistem bagi hasil. Penyempurnaan undang -undang no. 7 tahun 1992 menjadi undang -undang no 10 tahun 1998 yang secara tegas menyebutkan bahwa terdapat dua sistem pada sistem perbankan di Indonesia yaitu sistem perbankan konvensional dan perbankan syariah (data disampaikan pada lama berita OJK.go.id).

Sampai dengan akhir tahun 2019 sudah berdiri 14 Bank Umum Syariah (BUS) dan 20 Unit Usaha Syariah (UUS). Data perbandingan kinerja indikator antara bank syariah dengan bank konvensional menunjukkan sebagai beikut:

\begin{tabular}{|c|c|c|c|}
\hline \multicolumn{2}{|c|}{ Bank Syariah } & \multicolumn{2}{|c|}{ Bank Konvensional } \\
\hline Indikator & $\begin{array}{l}\text { Desember } \\
2019(\%)\end{array}$ & Indikator & $\begin{array}{l}\text { Desember } \\
2019(\%)\end{array}$ \\
\hline CAR & 20.59 & CAR & 23.40 \\
\hline ROA & 1.73 & ROA & 2.47 \\
\hline $\mathrm{NOM}$ & 1.92 & NIM & 4.91 \\
\hline BOPO & 84.45 & BOPO & 79.39 \\
\hline NPF Gross & 3.32 & NPL Gross & 2.5 \\
\hline FDR & 77.91 & LDR & 94.43 \\
\hline Market Share & 6.17 & Market Share & 93.83 \\
\hline
\end{tabular}

Pencapaian pangsa pasar (market share) perbankan syariah masih sangat jauh dari pangsa pasar industri dimana perbankan syaiah hanya mampu menyerap $6.17 \%$ sejak kemunculan bank syariah dalam kurun waktu tiga dekade, sementara bank konvensional yang lebih dulu berdiri (delapan dekade) telah memiliki market share sebesar 93.83\%, hal ini sangat bertolak belakang jika dibandingkan dengan jumlah populasi penduduk Indonesia yang merupakan mayoritas muslim dengan jumlah populasi sekitar $87 \%$ (data yang dikeluarkan oleh laman Alvara-strategic.com, Indonesia Moslem Report 2019, yang diposting oleh Hasanudin, 11/01/2020). Jika dilihat dari angka market share yang dimiliki oleh perbankan konvensional maka sampai dengan saat ini industri perbankan di Indonesia masih didominasi oleh perbankan konvensional.

Indikator profitabilitas yang tercermin pada rasio Return on Assets (ROA), kinerja profitabilitas bank syariah menunjukan bahwa bank syariah dalam mengelola seluruh asetnya menghasilkan return yang lebih kecil (1.73\%) dibanding bank konvensional $(2.47 \%)$ hal ini menunjukkan profitabilitas bank konvensional lebih baik dari bank syariah. Indikator kecukupan modal bank syariah masih menunjukan angka yang lebih kecil (20.59\%) dibanding bank konvensional $(23.40 \%)$ sehingga menunjukan kekuatan dan kemampuan modal bank konvensional lebih baik disbanding bank syariah.

Dalam hal penyaluran pembiayaan/kredit tingkat penyaluran bank konvensional $(94.43 \%)$ jauh lebih baik dibanding bank syariah (77.91\%) dimana hal ini akan berdampak kepada potensi untuk mendapatkan pendapatan akan lebih tinggi. Bank konvensional lebih baik dalam mengelola kredit yang disalurkan sehingga nilai kredit bermasalah yang dikelola oleh bank konvensional lebih kecil (2.5\%) dibandingkan dengan pembiayaan bermasalah yang dimiliki bank syariah $(3.32 \%)$. Penerapan efisiensi operasional perbankan konvensional menunjukan angka yang lebih baik (79.39\%) dibanding perbankan syariah $(84.45 \%)$.

Lambannya pertumbuhan perbankan syariah dalam meningkatkan pangsa pasar potensial dikemukakan penyebabnya dari hasil penelitian yang dilakukan oleh M Iqbal Fasa (2013), yaitu sebagai berikut:

1. Rasionalitas pemeluk Islam dalam berekonomi, masih berorientasi kepada pengejaran keuntungan materi dan tidak mempertimbangkan persoalan halal haram riba.

2. Masih rendahnya pemahaman masyarakat akan bank syariah.

3. Belum adanya dukungan yang bulat dari institusi keagamaan yang mendukung haramnya bunga sebagai riba.

4. Dalam operasional bank syariah masih kurang didukung regulasi yang mandiri. Dalam operasionalnya regulasi bank syariah masih bercampur dengan bank konvensional.

5. Rasionalitas penduduk muslim di Indonesia masih berorientasi pada pencairan keuntungan yang berarti pada saat bank syariah dapat memberikan return yang lebih baik dari bank konvensional maka masyarakat akan memilih bank syariah sementara disaat bank syariah memberi return lebih rendah dari bank konvensional maka bank syariah akan ditinggalkan.

Respon regulator terkait adanya fenomena tersebut seperti disampaikan pada lama berita Detik.Finance.com yang mengatakan, "Terdapat tujuh hambatan yang membuat bank syariah lambat 
berkembang di Republik Indonesia," kata Direktur Perbankan Syariah Otoritas Jasa Keuangan, Dhani Gunawan, pada rapat diskusi di Bogor, Sabtu (21/11/2015). yaitu sebagai berikut:

1. Masih belum selarasnya visi dan masih kurangnya koordinasi antar pemerintah dan otoritas dalam penegembangan perbankan syariah tersebut.

2. Perbankan syariah belum memiliki modal yang memadai sehingga bank syariah kesulitan mengembangkan usaha.

3. Struktur pendanaan perbankan syariah masih mengandalkan dana mahal sehingga pengembalian dana pada nasabah cukup tinggi.

4. Produk yang tidak variatif dan pelayanan yang belum sesuai ekspektasi konsumen.

5. Sumber daya manusia yang belum memadai serta teknologi informasi yang belum memadai.

6. Pemahaman dan kesadaran masyarakat yang masih rendah terhadap bank syariah.

7. Pengaturan dan pengawasan yang masih belum optimal.

\section{KAJIAN PUSTAKA DAN PERUMUSAN HIPOTESIS}

\subsection{Analisis Laporan Keuangan}

Akuntansi adalah suatu proses pencatatan, penggolongan, peringkasan yang menghasilkan informasi ekonomi untuk diberikan kepada pihak pengguna. Akuntansi keuangan menyediakan informasi yang dirancang untuk kebutuhan pengguna internal dan eksternal. Informasi tersebut disajikan kepada pengguna dalam bentuk laporan keuangan. Laporan keuangan yang dihasilkan perusahaan pada umumnya yaitu; neraca, laporan laba rugi dan laporan aliran kas (Faiz Zamzami,dkk. 2016).

Para pengguna laporan keuangan menggunakan laporan keuangan untuk berbagai kepentingan dengan menganalisis dan memahami laporan keuangan. Pengguna laporan keuangan yaitu pengguna internal dan pengguna eskternal. Pengguna internal terdiri dari manajemen perusahaan dan pegawai, sementara pengguna eksternal adalah investor, pemerintah, supplier, lembaga keuangan dan media. Para pengguna memiliki tujuan tertentu dalam menganalisis laporan keuangan perusahaan. (Kasmir. 2017).

Analisis laporan keuangan pada dasarnya dilakukan karena ingin mengetahui tingkat profitabilitas dan tingkat kesehatan perusahaan. Ada beberapa tujuan dilakukan analisis laporan keuangan yaitu investor, pemberian kredit, kesehatan supplier, kesehatan pelanggan, kesehatan perusahaan ditinjau dari karyawan, pemerintah dan analisis internal. (Mamduh, dkk. 2018).
Analisa laporan keuangan dapat dlakukan dengan melakukan analisa ratio keuangan. Laporan keuangan yang melaporkan aktivitas yang dituangkan dengan angka-angka. Angka-angka yang ada dalam laporan keuangan akan menjadi berarti dilakukan perbandingan antara satu komponen dengan komponen lainnya. Rasio keuangan merupakan kegiatan membandingkan angkaangka yang ada dalam laporan keunagan dengan cara membagi suatu angka dengan angka lainnya. (Kasmir. 2017)

Analisa laporan keuangan mencakup (1) membandingkan kinerja perusahaan dengan perusahaan lain dalam industri yang sama, (2) mengevaluasi tren perusahaan dari waktu ke waktu. Manager perusahaan menggunakan analisis keuangan untuk mengidentifikasi situasi yang membutuhkan perhatian. Pemberi pinjaman menggunakan analisis laporan keuangan untuk menilai kelayakan mendapat kredit. Dan pemegang saham menggunakan analisis keuangan untuk membantu memprediksi pendapatan masa depan, deviden dan arus kas. (Eugene F Brigham, dkk. 2012)

Analisis common size adalah analisis yang disusun dengan menghitung tiap-tiap rekening dalam laporan keuangan menjadi proporsi total penjualan (untuk laporan laba rugi) atau total aktiva (untuk neraca). Cara semacam ini memudahkan pembaca data-data keuangan dalam beberapa periode untuk mencari trentren tertentu (Mamduh, dkk. 2018).

\subsection{Profitabilitas}

Pengukuran kinerja yang dapat digunakan dalam mengukur kinerja suatu bank syariah melalui laporan keuangan yaitu dengan melihat tingkat profitabilitas bank tersebut. Dalam melakukan kegiatan operasionalnya, bank memiliki tujuan utama yaitu mencapai tingkat profitabilitas yang maksimal. Profitabilitas merupakan kemampuan bank untuk menghasilkan atau memperoleh laba secara efektif dan efisien. Profitabilitas perusahaan perbankan menunjukkan pendapatan yang mampu dihasilkan oleh perusahaan dalam satu atau setiap periode. Tingginya profitabilitas suatu bank dapat menunjukkan bahwa sebagian besar kinerja bank tersebut dapat dikatakan baik, karena diasumsikan bahwa bank telah beroperasi secara efektif dan efisien dan memungkinkan bank untuk memperluas usahanya (Fifit Syaiful Fitri, 2013).

Profitabilitas adalah sejumlah kebijkaan dan keputusan, perhitungan rasio mampu memberikan gambaran efektivitas operasional perusahaan. Rasio profitabilitas adalah perhitungan yang menunjukan berbagai perbandingan atas likuiditas, manajemen asset dan hasil operasional. (Eugene F Brigham, dkk. 2012).

Rasio profitabilitas merupakan rasio untuk menilai kemampuan perusahaan menghasilkan keuntungan. Rasio ini juga memberikan ukuran tingkat efektivitas manajemen suatu perusahaan. Rasio profitabilitas bagi pihak internal perusahaan dan eksternal perusahaan bertujutun; (1) mengukur atau menghitung laba yang 
diperoleh perusahaan dalam suatu periode tertentu (2) menilai posisi laba perusahaan tahun sebelumnya dengan tahun sekarang, (3) menilai perkembangan laba dari waktu ke waktu (4) mengukur produktivitas seluruh dana yang digunakan. Beberapa rasio profitabilitas yang selalu digunakan untuk menghitung profitabilitas adalah (1) Return on Investmen (ROI), (2) Return on Equity(ROE) (3) Return on Assets (ROA). (Kasmir. 2017).

Analisisis ROA digunakan untuk mengukur kemampuan perusahaan menghasilkan laba dengan menggunakan total asset (kekayaan) yang dimiliki perusahaan setelah disesuaikan dengan biaya-biaya untuk mendanai asset tersebut. ROA dapat diinterprestasikan sebagai hasil dari serangkaian kebijakan perusahaan (strategi) dan pengaruh dari faktor - faktor lingkungan (environmental factors). Analisis difokuskan pada profitabilitas aset, dan dengan demikian tidak memperhitungkan cara-cara untuk mendanai asset tersebut. (Mamduh, dkk. 2018).

Analisis Return On Asset (ROA) digunakan untuk mengukur kemampuan perusahaan menghasilkan laba dengan menggunakan total assest yang dipunyai perusahaan untuk mendanai asset tersebut. Analisis ini kemudian bisa diproyeksikan kemasa depan untuk melihat kemampuan perusahaan mengasilkan laba pada masa mendatang. Semakin tinggi nilai pencapaian laba maka semakin baik perusahaan dalam menggunakan assets untuk menghasilkan laba (Mamduh. 2018).

Berdasarkan uraian tersebut diatas untuk mengukur profitabilitas, variabel yang digunakan dalam penelitian ini diproksikan dengan Return On Assets (ROA). Return On Assets (ROA) mencerminkan kemampuan perusahaan menghasilkan laba dengan menggunakan seluruh asset yang didanai dan dikelola oleh perusahaan dan tercermin dalam laporan keuangan perusahaan.

Mengacu kepada peraturan Bank Indonesia (PBI no.13/1/PBI/2011) tentang penilaian kesehatan bank umum, Peraturan Otoritas Jasa Keuangan (POJK) No. 8.POJK.03/2014 tentang penilaian tingkat kesehatan bank umum syariah dan unit usaha syariah dan Lampiran Surat Edaran Bank Indonesia No. 6/10/PBI/2004 tentang sistem penilaian tingkat kesehatan bank umum. Salah satu pengukuran yang digunakan untuk mengukur earning profitabilitas adalah Return On Assets (ROA). Formulasi menghitung Return on Assets (ROA) mengacu pada lampiran SE BI No.6/10/PBI/2004 adalah sebagai berikut:

$$
\text { ROA } \frac{\text { Laba Sebelum Pajak }}{\text { Total Aktiva }} \times 100 \%
$$

\subsection{Risiko Bank}

Risiko merupakan suatu kejadian potensial, baik yang dapat diperkirakan (anticipated) maupun yang tidak dapat diperkirakan (unanticipated) yang berdampak negatif terhadap pendapatan dan permodalan bank. (Adiwarman A karim:2017).
Definisi lain risiko menurut Peraturan Otoritas Jasa Keuangan (POJK) no. 65/POJK.03/2016 yaitu risiko adalah potensi kerugian akibat terjadinya suatu peristiwa tertentu.

Mendefinisikan manajemen risiko secara sederhana adalah mengidentifikasi kejadian-kejadian yang dapat memberi konsekwensi kerugian dan kemudian mengambil tindakan untuk mencegah atau meminimalisir kerugian yang disebabkan oleh kejadian tersebut (Eugene F Brigham, Michael C Ehrhardt. 2012). Sementara menurut POJK no.65/POJK.03/2016 yaitu manajemen risiko adalah serangkaian metodologi dan prosedur yang digunakan untuk mengidentifikasi, mengukur, memantau, dan mengendalikan risiko yang timbul dari seluruh kegiatan usaha bank.

Pengaturan manajemen risiko bank syariah diatur dalam (POJK) no.65/POJK.03/2016 tentang Penerapan manajemen risiko bagi bank syariah umum syariah \& unit usaha syariah. Risiko dalam pengelolaan bank syariah terdiri atas:

1. Risiko kredit yaitu risiko akibat kegagalan nasabah atau pihak lain dalam memenuhi kewajiban kepada Bank sesuai dengan perjanjian yang telah disepakati.

2. Risiko pasar yaitu risiko pada posisi neraca dan rekening administratif akibat perubahan harga pasar antara lain risiko berupa perubahan nilai dari asset yang dapat diperdagangkan atau disewakan.

3. Risiko likuiditas yaitu risiko akibat ketidakmampuan bank untuk memenuhi kewajiban yang jatuh tempo dari sumber dana arus kas dan asset likuid berkualitas tinggi.

4. Risiko operasional yaitu risiko kerugian yang diakibatkan oleh proses internal yang kurang memadai, kegagalan proses internal, kesalahan manusia, kegagalan sistem, atau adanya kejadian eksternal yang dapat mempengaruhi opersional bank.

5. Risiko hukum yaitu risiko akibat tuntutan hukum dan atau kelemahan aspek yuridis.

6. Risiko reputasi yaitu risiko akibat menurunnya tingkat kepercayaan pemangku kepentingan (stakeholder) yang bersumber dari perspektif negatif terhadap bank.

7. Risiko stratejik yaitu risiko akibat ketidaktepatan dalam pengambilan atau pelaksanaan suatu keputusan stratejik serta kegagalan dalam mengantisipasi perubahan lingkungan bisnis.

8. Risiko kepatuhan yaitu risiko akibat bank tidak mematuhi atau tidak melaksanakan peraturan perundangan-undangan dan ketentuan yang berlaku serta prinsip syariah.

9. Risiko imbal hasil (rate of return risk) yaitu risiko akibat perubahan tingkat imbal hasil yang dibayarkan bank kepada nasabah, karena terjadi 
perubahan tingkat imbal hasil yang diterima bank dari penyeluran dana.

10. Risiko investasi (equity investment risk) yaitu risiko akibat bank ikut menanggung kerugian usaha nasabah yang dibiayai dalam pembiayaan berbasis bagi hasil.

Dari keterangan tersebut diatas diketahui bahwa risiko kredit atau risiko pembiayaan adalah risiko akibat kegagalan nasabah atau pihak lain dalam memenuhi kewajiban kepada bank sesuai dengan perjanjian yang telah disepakati. Kegagalan/wan prestasi nasabah/pihak lain dalam memenuhi kewajiban kepada bank mengakibatkan terjadinya pemburukan kualitas aktiva produktif yang dimiliki bank. Pengukuran risiko pembiayaan untuk melihat kualitas aktiva dengan membandingkan kelompok pembiayaan yang diklasifikasikan disbanding dengan jumlah pembiayaan syariah dapat menggunakan rasio Kualitas Aktiva Produktif (KAP) atau Non Performing Financing (NPF) dan pengukuran risiko pembiayaan untuk melihat volume penyaluran pembiayaan dibanding dengan dana milik bank dapat menggunakan rasio Financing to Debt Ratio (FDR).

\subsubsection{Non Performing Financing (NPF)}

Pengertian pembiayaan menurut undang-undang no 10 tahun 1998 yaitu penyediaan uang atau tagihan yang dapat disamakan dengan itu, berdasarkan persetujuan atau kesepakatan antara bank dengan pihak lain yang mewajibkan pihak yang dibiayai untuk mengembalikan uang atau tagihan tersebut setelah jangka waktu tertentu dengan imbalan atau bagi hasil. Dari definisi tersebut pembiayaan dipahami dapat berupa penyediaan uang tunai atau tagihan-tagihan yang dinilai dan diukur dengan uang.

Thamrin Abdullah,Sinta W (2018) mengemukakan bahwa proses penyaluran pembiayaan dimulai dengan melakukan penilaian kelayakan calon nasabah yang memenuhi kriteria dengan menerapkan aspek prudentiality principle yang memperhatikan aspek $5 \mathrm{C}$, yaitu sebagai berikut;

1. Characters, meyakinkani bahwa watak dari orang yang akan diberikan kredit, benar-benar dapat dipercaya. Hal ini tercermin dari latar belakang calon nasabah.

2. Capacity, melihat kapasitas nasabah dalam bidang bisnisnya termasuk kemampuan usahanya untuk membayar pembiayaan/kredit yang diberikan.

3. Capital, untuk melihat apakah modal yang dimiliki nasabah sudah dikelola seefektif mungkin, dianalisa melalui laporan keuangan nasabah.

4. Collateral, merupakan jaminan yang akan diserahkan baik fisik ataupun non fisik. Nilai jaminan sebaiknya melebihi nilai kredit jika terjadi pembiayaan macet makan akan lebih mudah dilakukan penyelesaiannya.
5. Condition. Menilai kondisi ekonomi terkini dihubungkan dengan prospek usaha nasabah kedepannya.

Non Performing Loan/Non Performing Financing (NPF) terjadi karena pengelolaan perbankan yang kurang baik dalam mengaplikasikan prinsip-prinsip kehati-hatian (prudential banking principle), padahal bank merupakan institusi keuangan yang sarat dengan batasan dan peraturan (the most regulated industry in the world). Disamping itu juga kurang ditaatinya kode etik bankir Indonesia yang diharapkan dapat menjadi pedoman moral bagi para bankir dalam melaksanakan tugasnya.(Abdul Ghofur Anshori. 2018).

Thamrin Abdullah, Sinta Wahjusaputri (2018) mengemukakan, sepandai-pandainya analis kredit dalam menganalisis setiap permohonan kredit, ada kemungkinan kredit tersebut mengalami kemacetan. Hal ini disebabkan oleh unsur sebagai berikut:

1. Dari pihak perbankan, artinya dalam melakukan analisis, pihak analis kurang teliti sehingga apa yang seharusnya terjadi tidak dapat diperkirakan sehingga analisa yang dilakukan lebih ke subjektif. Hal ini dapat pula terjadi akibat adanya kerjasama antara analis dan debitur.

2. Dari pihak nasabah, kemacetan terjadi dikarenakan, adanya unsur kesengajaan artinya nasabah tidak bermaksud membayar kewajibannya sehingga macet. Adanya unsur ketidaksengajaan artinya nasabah mau membayar namun nasabah tidak mampu karena terjadi masalah tertentu dalam usahanya, untuk permasalahan ini bank perlu melakukan penyelamatan dengan melakukan penyelamatan berupa; rescheduling, reconditioning, restructuting, dan combination.

Mengacu kepada PBI no.8/21/PBI/2006 tentang penilaian kualitas aktiva bank umum yang melaksanakan kegiatan usaha berdasarkan prinsip syariah. Klasifikasi kualitas pembiayaan adalah sebagai berikut:

\begin{tabular}{|c|l|l|}
\hline No & \multicolumn{1}{|c|}{$\begin{array}{c}\text { Klasifikasi/ } \\
\text { Kolektibilitas }\end{array}$} & $\begin{array}{l}\text { Cadangan khusus penyisihan } \\
\text { penghapusan aktiva }\end{array}$ \\
\hline 1. & Lancar & $\begin{array}{l}\text { 1\% dari seluruh aktiva produktif } \\
\text { yang digolongkan lancar setelah } \\
\text { dikurangi nilai agunan }\end{array}$ \\
\hline 2. & $\begin{array}{l}\text { Dalam } \\
\text { Perhatian } \\
\text { Khusus }\end{array}$ & $\begin{array}{l}5 \% \text { dari seluruh aktiva produktif } \\
\text { yang digolongkan DPK setelah } \\
\text { dikurangi nilai agunan }\end{array}$ \\
\hline 3 & $\begin{array}{l}\text { Kurang } \\
\text { Lancar }\end{array}$ & $\begin{array}{l}15 \% \text { dari seluruh aktiva } \\
\text { produktif yang digolongkan KL } \\
\text { setelah dikurangi nilai agunan }\end{array}$ \\
\hline 4. & Diragukan & $\begin{array}{l}50 \% \text { dari seluruh aktiva } \\
\text { produktif yang digolongkan } \\
\text { Diragukan setelah dikurangi } \\
\text { nilai agunan }\end{array}$ \\
\hline 5 & Macet & $\begin{array}{l}100 \% \text { dari seluruh aktiva } \\
\text { produktif yang digolongkan } \\
\text { Macet setelah dikurangi nilai } \\
\text { agunan }\end{array}$ \\
\hline
\end{tabular}

Sumber: Data Diolah Peneliti 
Formulasi menghitung KAP atau NPL/NPF mengacu pada lampiran SE BI No.6/10/PBI/2004 adalah sebagai berikut:

$$
\mathrm{KAP}=\frac{\begin{array}{l}
\text { Aktiva Produktif } \\
\text { Diklasifikasikan }
\end{array}}{\text { Total Aktiva Produktif }} \times 100 \%
$$

Aktiva produktif yang diklasifikasikan dihitung dari total pembiayaan yang masuk dalam kelompok kualitas kurang lancar (koletibilitas 3) sampai dengan kolektibilitas macet (koletibilitas 5). Batasan rasio minimal KAP/NPL/NPF (pembiayaan bermasalah) mengacu kepada PBI no.15/2/PBI/2013 adalah 5\% dari total kredit/pembiayaan. Ini berarti bahwa rasio NPF jika semakin kecil maka akan semakin baik dan sebaliknya.

Bank yang mengalami permasalahan dalam mengelola pembiayaan bermasalah dengan tingkat NPF net yang melebihi 5\% akan mendapat perhatian khusus dari regulator yaitu OJK dan Bank Indonesia berupa pemberlakukan batasan aktivitas dalam penyaluran pembiayaan dan aktivitas lainnya (beku operasional/freezing), bahkan pada kondisi terburuk, bank yang tidak mampu dalam memperbaiki kualitas pembiayaannya akan dilikuidasi atau ditutup.

\subsubsection{Financing to Deposit Ratio (FDR)}

Rasio total pembiayaan terhadap dana pihak ketiga (Financing to Deposit Ratio/FDR) adalah rasio yang menggambarkan perbandingan pembiayaan yang disalurkan dengan jumlah dana pihak ketiga yang dimiliki bank. Rasio ini masuk kedalam rasio likuiditas dimana rasio ini harus dipelihara dengan posisi tertentu yaitu 75 - 100\% (Sumartik, dkk. 2018).

Loan to Deposit Ratio merupakan rasio yang digunakan untuk mengukur komposisi jumlah kredit yang diberikan dibandingkan dengan jumlah dana masyarakat dan besarnya loan to deposit ratio menurut peraturan pemerintah maksimum adalah sebesar $110 \%$ (Kasmir. 2017).

Ketentuan penerapan Loan to Deposit Ratio (LDR) atau Financing to Deposit Ratio (FDR) Loan DR mengacu kepada PBI No.12/19/PBI/2010 tentang Giro Wajib Minimum Bank Umum dalam valas dan rupiah. Loan to Deposit Ratio adalah rasio kredit yang diberikan kepada pihak ketiga dalam rupiah dan valas terhadap dana pihak ketiga yang mencakup giro, tabungan dan deposito dalam rupiah dan valas, tidak termasuk dana antar bank. Formulasi untuk menghitung LDR mengacu pada lampiran SE BI No.6/10/PBI/2004. Untuk perbankan syariah menggunakan istilah Financing to Deposit Ratio (FDR) adalah:

$$
\text { FDR }=\frac{\text { Jumlah Kredit Yang Diberikan }}{\text { Total Dana Pihak Ketiga }}
$$

Berdasarkan uraian tersebut diatas rentang nilai rasio yang ideal untuk menilai rasio penyaluran kredit (LDR/FDR) adalah $75 \%$ hingga 100\%. Bank yang memiliki nilai FDR dibawah $75 \%$ berarti bank tersebut kesulitan dalam menyalurkan pembiayaan dari total dana pihak ketiga dan dapat berdampak kepada kemampuan bank untuk mendapat profit karena pendapatan utama bank didominasi oleh pendapatan atas penyaluran pembiayaan sementara bank yang memiliki nilai FDR diatas $100 \%$ menunjukan bahwa bank kesulitan menghimpun dana pihak ketiga sehingga harus menggunakan dana diluar bank (pinjaman) untuk disalurkan pada pembiayaam hal ini berdampak bank harus membayar kepada pemilik dana atas peminjaman dana tersebut dan hal ini dapat mempengaruhi profitabilitas bank karena bank harus membayar tambahan biaya dana.

\subsection{Kecukupan Modal}

Heri (2019) mengemukakan beberapa definisi modal adalah sebagai berikut:

1. Modal bank adalah dana yang diinvestasikan oleh pemilik dalam rangka pendirian badan usaha, yang dimaksudkan untuk membiayai kegiatan usaha bank disamping memenuhi peraturan yang ditetapkan.

2. Modal bank adalah sejumlah dana yang diinvestasikan dalam berbagai jenis usaha (Ventura) perbankan yang relevan.

3. Modal bank merupakan modal awal pada saat pendirian bank, yang jumlah nya telah ditetapkan dalam suatu ketentuan atau pendirian bank.

Dari uraian tersebut diatas dpat disimpulkan bahwa modal bank merupakan dana yang diinvestasikan pemilik. Untuk membiayai kegiatan usaha bank yang jumlahnya telah ditetapkan. Dalam industri perbankan, bank harus menyediakan modal inti dan modal pelengkap.

Rasio kecukupan modal adalah rasio perbandingan modal dan simpanan khususnya masyarakat harus dipadukan dengan memperhitungkan aktiva yang mengandung risiko, karena itu modal bank harus dilengkapi dengan berbagai cadangan sebagai penyangga modal, yang secara umum disebut dengan modal inti dan modal pelengkap (Thamrin Abdullah, dkk. 2018)

Mengacu pada ketentuan Peraturan Otoritas Jasa Keuangan (POJK) no.34/POJK.03/2016 tentang kewajiban penyediaan modal minimum bank umum. Bank wajib menyediakan modal minimum sesuai dengan profil risiko. Penyediaan modal minimum dihitung dengan menggunakan rasio kewajiban penyediaan modal minimum dari asset tertimbang menurut risiko (ATMR). Perhitungan dan pengukuran kecukupan modal dalam perbankan syariah menggunakan perhitungan yang sama dengan perhitungan yang digunakan oleh bank konvensional yaitu menggunakan perhitungan kewajiban penyediaan modal minimum (KPMM) sesuai dengan aturan regulator. Perhitungan KPMM biasa disebut juga dengan sebutkan rasio Capital Adequacy Ratio (CAR). 
Batasan rasio minimal KPMM sesuai PBI no. 15/2/PBI/2013 adalah sebesar $8 \%$ untuk bank dengan profil risiko 1. Bank dengan profil risiko 2, KPMM minimal sebesar 9\%, sampai dengan profil risiko 5 dimana bank harus menyediakan KPMM minimal $12 \%$.

Penetapkan batasan nilai CAR masing-masing bank dengan tingkat risiko yang dilaporakan bank pada periode laporan tertentu secara periodek, dengan tingkat CAR berjenjang sesuai tingkatan profil risiko.

Formulasi CAR adalah mengacu pada lampiran SE BI No.6/10/PBI/2004 sebagai berikut:

$$
\mathrm{CAR}=\frac{\text { Modal }}{\text { Aktiva Tertimbang Menurut Risiko }} \times 100 \%
$$

Regulator telah menetapkan batasan minimal dan tidak menetapkan batasan maksimal untuk tingkat CAR ini berarti tingkat CAR yang semakin tinggi akan semakin baik dan sebaliknya. Bank dengan tingkat CAR dibawah standar ketentuan akan diminta oleh regulator untuk melakukan penambahan modal untuk memenuhi batasan minimal CAR yang telah ditetapkan.

\subsection{Efisiensi Biaya Operasional}

Biaya operasional adalah biaya biaya yang terdiri dari; biaya produksi yaitu biaya-biaya yang berkaitan dengan proses pengolahan bahan baku menjadi produk selesai yang siap dijual. Sementara biaya keuangan (financial) adalah biaya yang berkaitan dengan fungsi penyediaan dana, misalnya biaya administrasi bank, biaya bunga, biaya provisi kredit (Indrayati, 2017).

Biaya operasional adalah (Operational Cost) adalah biaya yang diperlukan untuk melaksanakan kegiatan dalam proses produksi dan memiliki sifat habis pakai dalam kurun waktu singkat. Tujuan biaya operasional adalah untuk mengelola sumber ekonomi yang dimiliki perusahaan antara lain biaya gaji pegawai, listrik, air dan lainnya (Dadan Ramadhani, dkk. 2020)

Cost reduction strategies merupakan proses yang dilakukan oleh perusahaan untuk mengurangi biaya dan meningkatkan keuntungan. Pengurangan biaya pabrikan, administrasi, distribusi, penjualan, pemasaran, dan sumber daya manusia dengan mempertahankan karakteristik dan kualitas produk atau jasa. Tujuan perusahaan menerapkan cost reduction strategies adalah untuk meningkatkan efisiensi dan efektivitas karena perusahaan dinilai kurang efisien (Elvie Mulia. 2014). Efisiensi sering dikaitkan dengan perbandingan antara output dan input dimana semakin besar perbandingan output berbanding input maka akan semakin efisien suatu usaha (Mamduh. 2018).

Mengacu kepada POJK no. 6/POJK.3/2016 tentang kegiatan usaha dan jaringan kantor berdasarkan modal inti bank, disebutkan salah satu parameter untuk mengukur pencapaian efisiensi bank dapat diukur melalui rasio biaya operasional terhadap pendapatan operasional.semakin besar nilai biaya menunjukan semakin tidak efisien. Bank dengan nilai BOPO yang lebih kecil menunjukan kemampuannya dalam mengelola sumber daya diperusahaan dengan optimal sehingga mampu mencapai tujuan prusahaan untuk meningkat profitabilitas perusahaan. Formulasi untuk meghitung mengacu pada lampiran SE BI No.6/10/PBI/2004 BOPO adalah:

\section{$\mathrm{BOPO}=\frac{\text { Biaya Operasional }}{\text { Pendapatan Operasional }} \times 100 \%$}

Semakin kecil BOPO menunjukkan semakin efisien bank dalam menjalankan aktivitas usahanya. Bank yang sehat rasio BOPO nya kurang dari $100 \%$ sebaliknya bank yang kurang sehat rasio BOPO-nya lebih dari $10 \%$. Semakin tinggi biaya pendapatan bank berarti kegiatan operasionalnya semakin tidak efisien sehingga pendapatanya juga semakin kecil. Dengan kata lain tren BOPO berhubungan terbalik (negatif) terhadap tren profitabilitas bank.

\subsection{Hipotesis}

\subsubsection{Pengaruh Non Perforimg Financing (NPF) terhadap Return on Asset (ROA).}

Risiko Non Performing Financing (NPF) tidak berpengaruh negatif terhadap ROA, karena nilai ratarata NPF bank syariah di Indonesia dalam penelitian ini masih tergolong rendah sehingga diasumsikan bahwa tingkat pembiayaan macetnya juga rendah dan tidak sampai berefek terhadap laba bank syariah (Rima Yunita. 2014). Non Performing Financing (NPF) memiliki pengaruh tidak signfikan terhadap Return on Assets (ROA) hal ini disebabkan tingkat NPF selama masa penelitian masih tergolong rendah yakni masih dibawah 5\% (Ubaidillah. 2016).

NPF tidak memiliki pengaruh langsung yang signifikan terhadap ROA. Hal ini berarti bahwa kondisi NPF yang lebih besar dalam satu periode tidak secara langsung memberikan penurunan laba pada periode yang sama. Hal ini dikarenakan pengaruh yang signifikan dari NPF terhadap ROA adalah berkaitan dengan penentuan tingkat kemacetan pembiayaan yang diberikan oleh sebuah bank. Dalam hal ini karena pembiayaan merupakan sumber utama pendapatan bank. Di sisi lain adanya NPF yang tinggi akan dapat mengganngu perputaran modal kerja dari bank. Maka manakala bank memiliki jumlah pembiayaan macet yang tinggi, maka bank akan berusaha terlebih dahulu mengevaluasi kinerja mereka dengan sementara menghentikan penyaluran pembiayaannya hingga NPF berkurang. Dari data yang diperoleh, NPF bank syariah relatif kecil atau sedikit yang macet. Sehingga NPF tidak mempengaruhi profitabilitas bank syariah (Edhi Satriyo Wibowo,dkk. 2013).

Data nilai Non Performing Financing (NPF) yang digunakan dalam penelitian ini menggunakan nilai NPF Gross. Non Performing Financing (NPF) menunjukan nilai Non Performing Financing (NPF) sebelum dilakukan adjustement (penyesuaian) yang diperbolehkan oleh regulator. 
Berdasarkan pembahasan sebelumnya, hipotesis pertama dalam penelitian ini adalah:

$\mathrm{H}_{1}$ : Non Performing Financing (NPF) berpengaruh negatif terhadap Return on Asset (ROA) .

\subsubsection{Pengaruh Financing to Debt Ratio terhadap Return on Assets (ROA).}

$(F D R)$

Manajemen bank syariah memperhitungkan besaran Return on Assets (ROA) untuk menjadi dasar yang menentukan target Return on Assets (ROA) di masa depan. Sementara itu, pengaruh Financing to Deposit Ratio (FDR) terhadap ROA bisa diartikan bahwa Financing to Deposit Ratio (FDR) dalam jangka pendek dijadikan sumber informasi yang penting bagi manajemen bank syariah untuk mengoptimalkan kemampuan aset bank syariah untuk memperoleh mendapatkan yang maksimal (Heri Sudarsono. 2017).

Financing to Deposit Ratio (FDR) memiliki pengaruh positif terhadap ROA, yang berarti bahwa tinggi atau rendahnya FDR dapat memprediksi tinggi atau rendahnya ROA. Semakin tinggi nilai FDR suatu bank makan akan dapat memberikan tingkat profitabilitas yang lebih tinggi dibanding bank dengan memiliki tingkat FDR yang lebih rendah (Rima Yunita. 2014). Rasio Financing to Deposit Ratio (FDR) secara parsial berpengaruh positif dan signfikan terhadap Return on Assets (ROA) artinya kenaikan rasio FDR akan menyebabkan ROA naik. (Nur Mawaddah. 2015).

Financing to Deposit Ratio (FDR) memiliki pengaruh positif dan signifkan terhadap Return on Assests (ROA) artinya nilai FDR harus dijaga oleh bank syariah pada batas aman sesuai ketentuan regulator, sebab jika penyaluran pembiayaan terlalu tinggi akan menjadi ancaman bagi likuidtas bank sedangkan jika terlalu rendah maka bagi hasil yang ditawarkan kepada nasabah menjadi tidak menarik dan juga menunjukan bahwa bank tidak mampu menjalankan fungsinya sebagai intermediary secara optimal (Sri Windarti M. 2015).

FDR (Financing to Deposit Ratio) atau disebut juga dengan liquidity ratio menunjukan semakin tinggi atau besar dana masyarakat yang dapat dihimpun oleh perbankan dan disalurkan dalam bentuk pembiayaan secara tepat, efisien dan hati-hati maka akan meningkatkan pendapatan perbankan. Karena semakin tinggi FDR, maka semakin besar juga potensi untuk mencapai Return on Asset/ROA. Rasio FDR untuk bank syariah ini menunjukkan fungsi intermediasi suatu bank sehingga semakin baik pengelolaan fungsi intermediasi suatu bank, maka akan meningkatkan profitabilitas di tahun-tahun berikutnya (Ra Ida Wahyu, dkk. 2017).

Berdasarkan pembahasan sebelumnya, hipotesis kedua dalam penelitian ini adalah:

$\mathrm{H}_{2}$ : Financing to Deposit Ratio (FDR) berpengaruh positif terhadap Return on Asset (ROA).

\subsubsection{Pengaruh Capital Adequacy Ratio (CAR) terhadap return on Assets (ROA).}

Capital (permodalan) adalah kemampuan bank dalam mempertahankan modal yang mencukupi dan kemampuan manajemen bank dalam mengidentifikasi, mengukur, mengawasi dan mengontrol risiko-risiko yang timbul yang dapat berpengaruh terhadap besarnya modal bank. CAR tidak berpengaruh signifikan terhadap ROA di masa depan karena ada faktor-faktor lain mengenai tingginya biaya operasional Bank Syariah yang berpengaruh terhadap laba bank syariah. (Ra Ida, Wahyu, dkk. 2017). Capital Adeqacy Ratio (CAR) berpengaruh positif terhadap Return on Assets (ROA) yang artinya tinggi atau rendahnya CAR dapat memprediksi tinggi atau rendahnya nilai Return on Assets (ROA) (Rima Yunita. 2014).

Dari uraaian tersebut diatas Capital Adequacy Ratio (CAR) yang biasa disebut dengan kecukupan modal, yang berarti jumlah modal sendiri yang diperlukan untuk menutup risiko kerugian yang mungkin timbul dari penanaman aktiva-aktiva yang mengandung risiko serta membiayai seluruh benda tetap dan inventaris bank. Manajemen bank perlu mempertahankan atau meningkatkan nilai CAR sesuai ketentuan Bank Indonesia karena dengan modal yang cukup, maka bank dapat melakukan ekspansi usaha dengan lebih aman dalam rangka meningkatkan profitabilitasnya.

Berdasarkan pembahasan sebelumnya, hipotesis ketiga dalam penelitian ini adalah:

$\mathrm{H}_{3}$ : Capital Adequacy Ratio (CAR) berpengaruh positif terhadap Return on Asset (ROA).

\subsubsection{Pengaruh Biaya Operasional Pendapatan Operasional (BOPO) terhadap Return on Assets (ROA).}

Biaya Operasional pada Pendapatan Operasional (BOPO) dihitung dengan membandingkan total biaya operasionalnya dengan total pendapatan operasional. Nilai BOPO yang baik berkisar antara $75 \%$ hingga $90 \%$. Jika suatu perusahaan mempunyai nilai BOPO diatas $90 \%$ maka perusahaan tersebut tidak sehat karena beban operasional perusahaan yang tidak diimbangi dengan baik oleh pendapatan operasionalnya (Rima Yunita. 2014).

Tingkat efisiensi bank dalam menjalankan operasinya berpengaruh terhadap tingkat pendapatan yang dihasilkan oleh bank. Jika kegiatan operasional dilakukan dengan efisien maka pendapatan yang dihasilkan bank tersebut akan naik. Sehingga semakin besar rasio efisiensi maka semakin menurun kinerja keuangan perbankan. Begitu juga sebaliknya, jika rasio biaya operasional terhadap pendapatan operasional semakin kecil (Ratnawaty M. 2018).

Biaya Operasional pada Pendapatan Operasional (BOPO) digunakan untuk mengukur kemampuan manajemen bank dalam mengendalikan biaya 
operasional terhadap pendapatan operasional yang dikeluarkan oleh bank, sehingga kemngkinan suatu bank dalam kondisi bermasalah dapat diminimalisir, semakin efisien kinerja operasional suatu bank maka profitabilitas yang diperoleh semakin besar. Oleh karena itu perlu diperhatikan mengenai pengendalian biaya sehingga dapat dihasilkan rasio BOPO sesuai dengan ketentuan yang telah ditetapkan.

Berdasarkan uraian tersebut diatas kemampuan dalam mengelola besarnya biaya operasional yang dikeluarkan harus dilakukan harus menjadi perhatian manajemen selain meningkatkan pendapatan bank melalui peningkatan sumber-sumber pendapatan yang dapat dilakukan oleh bank. Kemampuan bank dalam pengelola biaya operasional untuk memaksimalkan pendapatan operasional dapat diketahui dari besaran rasio BOPO.

Berdasarkan pembahasan sebelumnya, hipotesis keempat dalam penelitian ini adalah:

$\mathrm{H}_{4}$ : Biaya Operasional (BOPO) berpengaruh negatif terhadap Return on Assets (ROA).

\section{METODE PENELITIAN}

\subsection{Populasi dan Sampel}

Populasi dalam penelitian ini adalah perusahaan LQ45 yang terdaftar di Bursa Efek Indonesia (BEI) periode tahun 2015 sampai 2019.

Kriteria yang digunakan dalam penelitian ini berdasarkan penggunaan metode purposive sampling, dengan kriteria sebagai berikut:

1. Perusahaan yang selalu listing di Indeks LQ45 yang selama periode tahun 2015 sampai dengan 2019, artinya laporan keuangan haruslah selalu terdaftar di Perusahaan Indeks LQ45 pada Bursa Efek Indonesia selama lima Perusahaan Indeks LQ45 yang tidak memenuhi kriteria variabel Penelitian.

2. Perusahaan indeks LQ45 yang memiliki data yang lengkap berhubungan dengan variabel penelitian yakni Return On Investment, Quick Ratio, Current Ratio, Debt To Total Asset, Earning Per Share, Firm Size Dan Dividen Tunai.

3. Selama periode penelitian, perusahaan membagikan dividen. Alasannya bertujuan untuk memaksimalkan kemakmuran bagi para pemegang saham.

\subsection{Operasional Variabel}

Variabel yang digunakan dalam penelitian ini terdiri dari variabel bebas (independen) adalah Return On Investment, Quick Ratio, Current Ratio, Debt To Total Asset, Earning Per Share, Firm Size Dan Dividen Tunai, kemudian variabel dependen dalam penelitian ini adalah Dividen Kas.
Tabel 1. Operasionalisasi Variabel

\begin{tabular}{|c|c|c|c|c|c|}
\hline No & Variabel & Definisi & Pengukuran & Jenis data & Skala \\
\hline 1. & $\begin{array}{l}\text { Return } \\
\text { (Hanafi, } \\
\text { 2018) }\end{array}$ & $\begin{array}{l}\text { Rasio yang } \\
\text { mengukur } \\
\text { kemampuan } \\
\text { perusahaan } \\
\text { secara } \\
\text { keseluruhan } \\
\text { didalam } \\
\text { menghasilkan } \\
\text { keuntungan } \\
\text { dengan jumlah } \\
\text { keseluruhan } \\
\text { aktiva yang } \\
\text { tersedia didalam } \\
\text { perusahaan }\end{array}$ & $\frac{\text { Laba Setelah Pajak }}{\text { Total Investasi }}$ & Sekunder & Rasio \\
\hline 2. & $\begin{array}{l}\text { Quick } \\
\text { Ratio } \\
\text { (Kasmir } \\
\text {,2016) }\end{array}$ & $\begin{array}{lr}\text { Rasio yang } \\
\text { mengukur } \\
\text { kemampuan } \\
\text { aktivar lancar } \\
\text { yang paling } \\
\text { likuid mampu } \\
\text { melunasi hutang } \\
\text { lancar. } & \\
\end{array}$ & $\frac{\text { Aktiva lancar - persediaan }}{\text { Kewajiban Lancar }}$ & Sekunder & Rasio \\
\hline 3. & $\begin{array}{l}\text { Current } \\
\text { Ratio } \\
\text { (Munaw } \\
\text { ir,2014) }\end{array}$ & $\begin{array}{lr}\text { Rasio } & \text { yang } \\
\text { dihitung dengan } \\
\text { membagi aktiva } \\
\text { lancar (current } \\
\text { assets) dengan } \\
\text { hutang atau } \\
\text { kewajiban lancar } \\
\text { (current liability) }\end{array}$ & $\frac{\text { Aktiva Lancar }}{\text { Kewajiban Lancar }}$ & Sekunder & Rasio \\
\hline 4. & $\begin{array}{l}\text { Debt to } \\
\text { Total } \\
\text { Asset } \\
\text { (Hery, } 2 \\
015 \text { ) }\end{array}$ & $\begin{array}{l}\text { Rasio yang } \\
\text { digunakan untuk } \\
\text { mengukur } \\
\text { perbandingan } \\
\text { antara total } \\
\text { hutang dan total } \\
\text { asset }\end{array}$ & $\frac{\text { Total Aktiva }}{\text { Total Kewajiban }}$ & Sekunder & Rasio \\
\hline 5. & $\begin{array}{l}\text { Earning } \\
\text { Per } \\
\text { Share } \\
\text { (Haraha } \\
\text { p,2018) }\end{array}$ & $\begin{array}{lr}\text { Rasio } & \text { yang } \\
\text { menggambarkan } \\
\text { jumlah rupiah } \\
\text { yang } & \text { diperoleh } \\
\text { untuk } & \text { setiap } \\
\text { lembar } & \text { saham } \\
\text { biasa } & \\
\end{array}$ & $\frac{\text { Laba Setelah Pajak }}{\text { Jumlah Lembar Saham }}$ & Sekunder & Rasio \\
\hline 6. & $\begin{array}{l}\text { Firm } \\
\text { size } \\
\text { (Juming } \\
\text { an,2011 } \\
\text { ) }\end{array}$ & $\begin{array}{l}\text { Firm Size } \\
\text { (Ukuran } \\
\text { perusahaan) } \\
\text { Ukuran } \\
\text { perusahaan ini } \\
\text { diukur dengan } \\
\text { menghitung total } \\
\text { asset yang ada } \\
\text { pada masing- } \\
\text { masing } \\
\text { perusahaan }\end{array}$ & $\begin{array}{l}\text { Logaritma Natural } \\
\text { dari Total Asset }\end{array}$ & Sekunder & Rasio \\
\hline 7. & $\begin{array}{l}\text { Dividen } \\
\text { Kas } \\
\text { (Hanafi, } \\
\text { 2018) }\end{array}$ & $\begin{array}{lr}\text { Dividen } & \text { yang } \\
\text { diberikan } & \text { oleh } \\
\text { perusahaan } & \\
\text { kepada } & \text { para } \\
\text { pemegang } & \\
\text { sahamnya } & \text { dalam } \\
\text { bentuk } & \text { uang } \\
\text { tunai } & \\
\end{array}$ & Total Dividen Kas & Sekunder & Rasio \\
\hline
\end{tabular}

Sumber: Penelitian Terdahulu

\subsection{Metode Analisis Data}

Penelitian melakukan pengujian dengan menggunakan analisis regresi linier berganda, yaitu metode statistik yang meneliti hubungan variabel terikat (dependen) dengan berbagai variabel terikat (independen). Model regresi yang akan dipakai untuk penelitian ini adalah sebagai berikut:

$Y=a+b_{1} X_{1}+b_{2} X_{2}+b_{3} X_{3}+b_{4} X_{4}+b_{5} X_{5}+b_{6} X_{6}+e$

Keterangan:

$Y \quad=$ Dividen Kas 


$$
\begin{array}{ll}
X_{1} & =\text { Return On Investment } \\
X_{2} & =\text { Quick Ratio } \\
X_{3} & =\text { Current Ratio } \\
X_{4} & =\text { Debt to Total Asset } \\
X_{5} & =\text { Earning Per Share } \\
X_{6} & =\text { Firm Size } \\
\mathrm{E} & =\text { Error } \\
a & =\text { Konstanta } \\
\mathrm{b}_{1}-\mathrm{b}_{3} & =\text { Koefesien Regresi }
\end{array}
$$

\section{HASIL DAN PEMBAHASAN}

\subsection{Statistik Deskriptif}

Tabel 2. Hasil Statistik Deskriptif

\begin{tabular}{|l|cc|c|cc|}
\hline Variabe1 & Max & Min & Mean & Std. Dev & N \\
Y & $2.600,00$ & 19,00 & 801,33 & 636,0963 & 75 \\
X1 & 0,4666 & 0,0113 & 0,1314 & 0,1099 & 75 \\
\hline X2 & 4,3206 & 0,2028 & 1,4768 & 0,9771 & 75 \\
\hline X3 & 4,8866 & 0,3114 & 1,9492 & 1,1501 & 75 \\
\hline $\mathrm{X} 4$ & 7,5153 & 1,3018 & 2,8942 & 1,6081 & 75 \\
$\mathrm{X} 5$ & $4.049,62$ & 26,84 & 684,1272 & 910,0835 & 75 \\
$\mathrm{X} 6$ & 19,6743 & 15,1737 & 17,4462 & 1,1713 & 75 \\
\hline
\end{tabular}

Earning Per Share dari perusahaan selama periode pengamatan (2015-2019) dapat dilihat pada table diperoleh sebesar 684,1272 dengan nilai standar deviasi adalah 910,0835. Nilai standar deviasi dari Earning Per Share lebih besar dari standar deviasi rata-rata, hal ini menunjukkan data Earning Per Share bervariasi atau heterogen. Sementara variabel yang lain yaitu Return On Investment, Quick Ratio, Current Ratio, Debt to Total Asset dan Firm Size memiliki hasil perhitungan standar deviasi yang lebih kecil dari rata-rata yang berarti data dari keempat variabel tersebut homogen.

\subsection{Uji Asumsi Klasik}

\subsubsection{Uji Normalitas}

Uji ini memiliki tujuan menguji setiap variabel didalam model regresi berdistribusi normal atau tidak. Uji normalitas dilihat dengan menggunakan grafik normal P-P plot. Normalitas terjadi apabila penyebaran data(titik) yang terletak pada sumbu diagonal dari grafik normal.

Hasil uji normalitas dapat dilihat dari grafik pada gambar berikut ini :

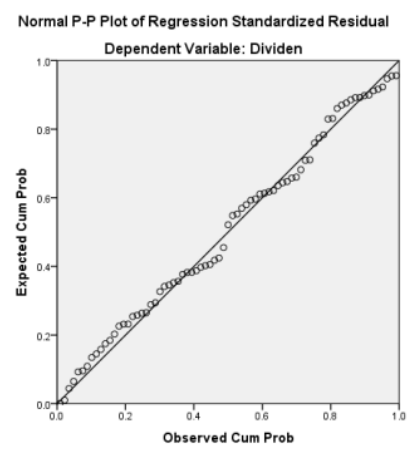

Sumber:Hasil pengolahan data dengan SPSS
Apabila dilihat dari Grafik 2, data menyebar disekitaran garis grafik histogram lalu mengikuti arah garis diagonal atau garis grafik histogramnya menunjukan pola distribusi normal, maka dapat disimpulkan bahwa model regresi memenuhi asumsi

\subsubsection{Uji Multikolinearitas}

Tabel 3. Hasil Uji Multikolinearitas

\begin{tabular}{|c|c|c|c|}
\hline \multirow{2}{*}{ Variabel } & \multicolumn{2}{|c|}{ Coliniearity Statistics } & \multirow{2}{*}{ Kesimpulan } \\
\cline { 2 - 3 } & $\begin{array}{c}\text { Tolerance } \\
\text { Value }\end{array}$ & VIF & \multirow{2}{*}{$\begin{array}{c}\text { Tidak terjadi } \\
\text { multikolinieritas }\end{array}$} \\
\hline X1 & 0.568 & 1.761 & $\begin{array}{c}\text { Tidak terjadi } \\
\text { multikolinieritas }\end{array}$ \\
\hline X2 & 0.121 & 8.253 & $\begin{array}{c}\text { Tidak terjadi } \\
\text { multikolinieritas }\end{array}$ \\
\hline X4 & 0.108 & 9.291 & $\begin{array}{c}\text { Tidak terjadi } \\
\text { multikolinieritas }\end{array}$ \\
\hline X5 & 0.597 & 1.675 & $\begin{array}{c}\text { Tidak terjadi } \\
\text { multikolinieritas }\end{array}$ \\
\hline X6 & 0.513 & 1.948 & $\begin{array}{c}\text { Tidak terjadi } \\
\text { multikolinieritas }\end{array}$ \\
\hline
\end{tabular}

Sumber: Hasil pengolahan data dengan SPSS

Hasil uji multikolinieritas menunjukan bahwa semua variable penelitian memiliki nilai VIF (variance inflation factor) di atas lebih kecil dari 10, dimana nilai terendah 1,025 dan tertinggi 7,409 lebih kecil dari 10 $(<10)$ batas nilai toleransi yang ditentukan dalam penelitian ini, artinya bilai nilai VIF lebih kecil 10 dari batas nilai toleransi yang ditentukan adalah tidak terjadi multikolinieritas atau tidak terjadi hubungan antara setiap variable yang ada dalam model penelitian.

\subsubsection{Uji Heterokedastisitas}

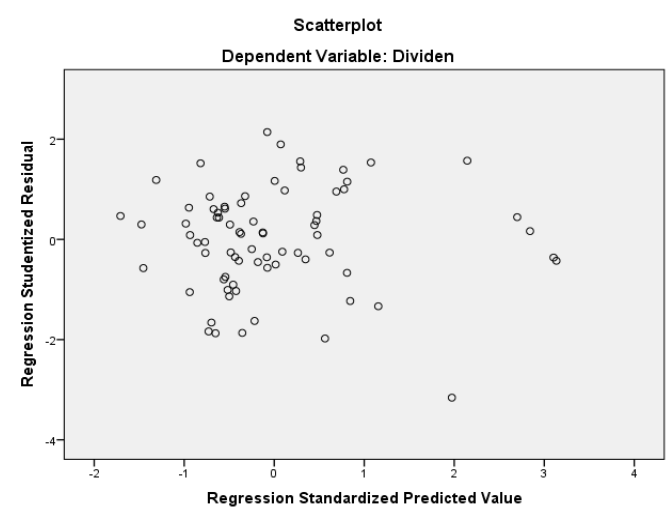

Sumber: Hasil pengolahan data dengan SPSS

\section{Gambar 3. Grafik Scatterplot}

Grafik scatterplot menunjukkan tidak terjadi heterokedastisitas. Hal ini berdasarkan grafik dimana titik-titik yang ada didalam grafik tidak membentuk pola tertentu yang jelas dan titik-titik tersebut tersebar diatas dan dibawah angka 0 pada sumbu $Y$.

Gambar 2. Hasil Uji Normalitas Data 


\subsubsection{Uji Autokorelasi}

Tabel 4. Hasil Uji Autokorelasi Data dengan Durbin-Watson

\begin{tabular}{|c|c|c|c|c|c|}
\hline \multicolumn{6}{|c|}{ Model Summaryb } \\
\hline $\begin{array}{l}\text { Mod } \\
\text { el }\end{array}$ & $\mathrm{R}$ & $\begin{array}{c}\mathrm{R} \\
\text { Square }\end{array}$ & $\begin{array}{l}\text { Adjusted R } \\
\text { Square }\end{array}$ & $\begin{array}{l}\text { Std. Error of } \\
\text { the Estimate }\end{array}$ & $\begin{array}{l}\text { Durbin- } \\
\text { Watson }\end{array}$ \\
\hline 1 & $.886^{\mathrm{a}}$ & .785 & .766 & .59043 & 1.769 \\
\hline
\end{tabular}

a. Predictors: (Constant), Return, Quick, Current, Debt, Earning, Firm

b. Dependent Variable: Dividen

Sumber: Hasil pengolahan data dengan SPSS

Nilai Durbin Watson dapat dilihat dari Tabel 4 di atas, Durbin Watson $(\mathrm{D}-\mathrm{W})=2.229$, sehingga dapat disimpulkan bahwa tidak ada autokorelasi dengan ditunjukkan $1<1.769$ (nilai DW) $<3$.

\subsection{Uji Regresi Berganda}

Analisis ini digunakan untuk mengukur kekuatan dua variabel atau lebih dan juga menunjukkan arah hubungan antar variabel dependen dengan variabel independen. Perhitungan analisis regresi dapat dilihat pada tabel 5 berikut ini:

\section{Tabel 5. Hasil Analisis Regresi Linear Berganda}

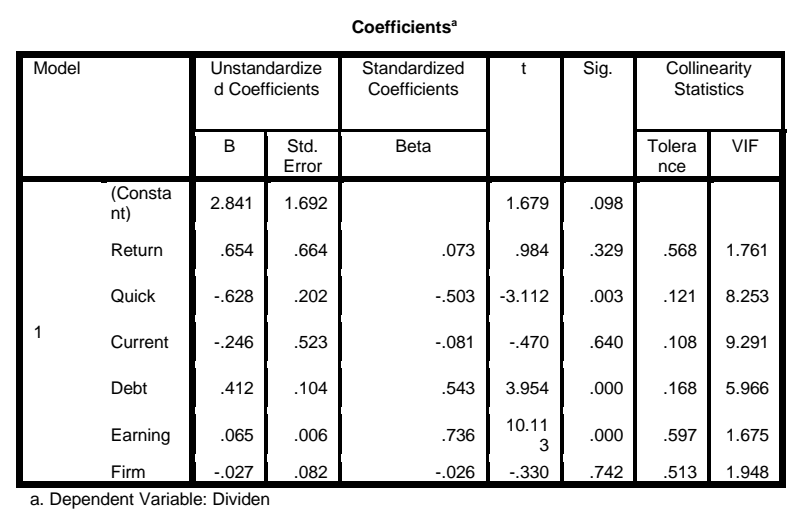

Sumber: Hasil pengolahan data dengan SPSS

Dari tabel di atas dapat disusun persamaan regresi linier berganda sebagai berikut:

$$
\begin{aligned}
\text { Dividen Kas }= & 2,841+0,654 \text { Return }-0,628 \text { Quick } \\
& -0,246 \text { Current }+ \text { 0,412 Debt }+ \\
& \text { 0,065 Earning }- \text { 0,027 Firm }
\end{aligned}
$$

Persamaan linier berganda tersebut dapat diinterpretasikan sebagai berikut:

1. Nilai konstanta $(\alpha)$ sebesar 2,841 menunjukkan bahwa selama periode pengamatan, rata-rata dividen kas sebesar Rp. 2,841. Dalam hal ini apabila semua variabel independen sama dengan 0 (nol).

2. Koefisien regresi untuk Return On Investment ( $\beta 1)$ sebesar 0,654 artinya setiap perubahan satu satuan rasio keuangan Return On Investment, maka dividen kas akan mengalami kenaikan sebesar 0,654 satuan. Dalam hal ini faktor lain yang mempengaruhi dividen kas dianggap tetap.
3. Koefisien regresi untuk Quick Ratio $(\beta 2)$ sebesar 0,628 artinya setiap perubahan satu satuan rasio keuangan Quick Ratio, maka dividen kas akan mengalami penurunan 0,628 satuan. Dalam hal ini faktor lain yang mempengaruhi dividen kas dianggap tetap.

4. Koefisien regresi untuk Current Ratio ( $\beta 2)$ sebesar $-0,246$ artinya setiap perubahan satu satuan rasio keuangan Current Ratio, maka dividen kas akan mengalami penurunan 0,246 satuan. Dalam hal ini faktor lain yang mempengaruhi dividen kas dianggap tetap.

5. Koefisien regresi untuk Debt to Total Asset sebesar 0,412 artinya setiap perubahan satu satuan rasio keuangan Debt to Total Asset, maka dividen kas akan mengalami kenaikan 0,412 satuan. Dalam hal ini faktor lain yang mempengaruhi dividen kas dianggap tetap.

6. Koefisien regresi untuk Earning Per Share ( $\beta 3)$ 0,065 artinya setiap perubahan satu satuan rasio keuangan Earning Per Share, maka dividen kas akan mengalami kenaikan sebesar 0,065 satuan. Dalam hal ini faktor lain yang mempengaruhi dividen kas dianggap tetap.

7. Koefisien regresi untuk Firm Size $(\beta 4)$ sebesar 0,027 artinya setiap perubahan satu satuan rasio keuangan Firm Size, maka dividen kas akan mengalami penurunan sebesar 0,027 satuan.

\subsection{Pengujian Hipotesis}

\subsubsection{Uji Parsial (Uji t)} bahwa:

Hasil uji parsial (uji t) pada Tabel 5 menunjukkan

1. Pengaruh Return On Investment terhadap Dividen Tunai dapat dilihat dengan memperhatikan nilai probabilitas signifikan dapat dilihat pada tabel 5 sebesar 0,098. Karena 0,098>0,05 atau 5\%(derajat kepercayaan), kesimpulannya Return On Investment secara signifikan tidak berpengaruh terhadap dividen kas.

2. Pengaruh Quick Ratio terhadap Dividen Tunai dapat dilihat dengan memperhatikan nilai probabilitas signifikan dapat dilihat pada tabel 5 sebesar 0,032<0,05 atau 5\%(derajat kepercayaan), kesimpulannya Quick Ratio secara signifikan berpengaruh terhadap dividen kas.

3. Pengaruh Current Ratio terhadap Dividen Tunai dapat dilihat dengan memperhatikan nilai probabilitas signifikan dapat dilihat pada tabel 5 sebesar 0,640>0,05 atau 5\%(derajat kepercayaan), kesimpulannya Current Ratio secara signifikan tidak berpengaruh terhadap dividen kas.

4. Pengaruh Debt to Total Asset terhadap Dividen Tunai dapat dilihat dengan memperhatikan nilai probabilitas signifikan dapat dilihat pada tabel 5 sebesar $0,000<0,05$ atau 5\%(derajat kepercayaan), kesimpulannya Debt to Total Asset secara signifikan tidak berpengaruh terhadap dividen kas.

5. Pengaruh Earning Per Share terhadap Dividen Tunai dapat dilihat dengan memperhatikan nilai 
probabilitas signifikan dapat dilihat pada tabel 5 sebesar $0,000<0,05$ atau $5 \%$ (derajat kepercayaan), kesimpulannya Earning Per Share secara signifikan tidak berpengaruh terhadap dividen kas.

6. Pengaruh Firm Size terhadap Dividen Tunai dapat dilihat dengan memperhatikan nilai probabilitas signifikan dapat dilihat pada tabel 5 sebesar 0,742> 0,05 atau 5\%(derajat kepercayaan), kesimpulannya Firm Size secara signifikan tidak berpengaruh terhadap dividen kas.

\subsubsection{Uji Simultan (Uji F)}

Tabel 6. Hasil Uji Simultan (Uji F)

\begin{tabular}{|c|c|c|c|c|c|c|}
\hline \multicolumn{7}{|c|}{ ANOVA $^{\mathrm{a}}$} \\
\hline \multicolumn{2}{|c|}{ Model } & Sum of & df & Mean & $\mathrm{F}$ & Sig. \\
\hline \multirow{3}{*}{1} & Regression & 86.442 & 6 & 14.407 & 41.327 & $.000^{\mathrm{b}}$ \\
\hline & Residual & 23.705 & 68 & .349 & & \\
\hline & Total & 110.147 & 74 & & & \\
\hline
\end{tabular}

a. Dependent Variable: Dividen

b. Predictors: (Constant), Firm, Earning, Debt, Return, Quick, Current

Sumber: Hasil pengolahan data dengan SPSS

Tabel di atas diketahui bahwa nilai probabilitas (probabilitas value) yang diukur pada penelitian tersebut yaitu sebesar $0,000>0,05$ atau 5\%(derajat kepercayaan) sehingga hipotesis diterima. Kesimpulannya yaitu Return On Investment, Quick Ratio, Current Ratio, Debt to Total Asset, Earning Per Share dan Firm Size berpengaruh secara simultan terhadap Dividen Tunai.

\subsubsection{Uji Koefisien Determinasi}

\section{Tabel 7. Hasil Uji Koefisien Determinasi}

\begin{tabular}{|l|r|r|r|c|}
\hline Model & \multicolumn{1}{|c|}{ Model Summary } \\
\hline 1 & $.886^{\mathrm{a}}$ & .785 & \multicolumn{1}{c|}{$\begin{array}{c}\text { Adjusted R } \\
\text { Square }\end{array}$} & $\begin{array}{c}\text { Std. Error of the } \\
\text { Estimate }\end{array}$ \\
\hline
\end{tabular}

a. Predictors: (Constant), Firm, Earning, Debt, Return, Quick, Current

b. Dependent Variabel: Dividen

Sumber: Hasil pengolahan data dengan SPSS

Koefisien determinasi (R2) mempunyai nilai 0,785. Hal ini membuktikan besarnya pengaruh variabel bebas (independen) yakni Return On Investment, Quick Ratio, Earning Per Share dan Firm Size terhadap variabel bebas (dependen) yakni Dividen Kas, bisa dijelaskan dalam model persamaan tersebut adalah sebesar $79 \%$ lalu sisanya $21 \%$ telah dipengaruhi oleh faktor-faktor lainnya yang tidak termasuk dalam model regresi.

\subsection{Pembahasan}

1. Pada hipotesis yang pertama (H1) yang menyatakan bahwa "Return On Investment memiliki pengaruh terhadap dividen kas"adalah tidak terbukti. Hasilnya diterangkan dengan besarnya Sig.t (nilai signifikansi t) adalah sebesar 0,098> 0,05 atau 5\%(derajat kepercayaan). Sehingga dapat dikatakan tidak adanya pengaruh yang signifikan dari variabel Return On Investment terhadap dividen kas. Dari hasil analisis dapat diketahui bahwa laba ternyata tidak digunakan untuk pembayaran dividen.

2. Pada hipotesis yang kedua (H2) yang menyatakan bahwa "Quick Ratio memiliki pengaruh terhadap dividen kas"adalah terbukti. Hasilnya diterangkan dengan besarnya Sig.t (nilai signifikansi t) adalah sebesar $0,003<0,05$ atau $5 \%$ (derajat kepercayaan). Sehingga dapat dikatakan tidak adanya pengaruh yang signifikan dari variabel Quick Ratio terhadap dividen kas. Hasil ini mengindikasikan bahwa Quick Ratio sangat diperhatikan manajemen perusahaan dalam mempertimbangkan keputusan untuk membayarkan besarnya dividen kas yang akan diberikan.

3. Pada hipotesis yang ketiga (H3) yang menunjukkan "Current Ratio memiliki pengaruh terhadap dividen kas"adalah tidak terbukti. Hasilnya diterangkan dengan besarnya Sig.t (nilai signifikansi t) adalah sebesar 0,640>0,05 atau 5\%(derajat kepercayaan). Sehingga dapat dikatakan bahwa variabel Current Ratio tidak berpengaruh signifikan terhadap dividen kas. Tidak signifikan disini menunjukkan bahwa Current Ratio tidak terlalu terhadap dividen kas. Perusahaan menggunakan laba yang diperoleh untuk menjaga likuiditas perusahaan.

4. Pada hipotesis yang keempat (H4) yang menyatakan bahwa "Debt to Total Asset memiliki pengaruh terhadap dividen kas"adalah terbukti. Hasilnya diterangkan dengan besarnya Sig.t (nilai signifikansi t) adalah sebesar $0,000<0,05$ atau 5\%(derajat kepercayaan). Sehingga dapat dikatakan bahwa variabel Debt to Total Asset mempunyai pengaruh yang signifikan terhadap dividen kas. Hasil ini mengindikasikan bahwa Debt to Total Asset sangat diperhatikan manajemen perusahaan dalam mempertimbangkan keputusan untuk membayarkan besarnya dividen kas yang akan diberikan.

5. Pada hipotesis yang kelima (H5) yang menunjukkan"Earning Per Share memiliki pengaruh terhadap dividen kas"adalah terbukti. Hasilnya diterangkan dengan besarnya Sig.t (nilai signifikansi t) adalah sebesar $0,000<0,05$ atau 5\%(derajat kepercayaan). Sehingga dapat dikatakan bahwa variabel Earning Per Share mempunyai pengaruh yang signifikan terhadap dividen kas. Hasil ini mengindikasikan bahwa Earning Per Share sangat diperhatikan manajemen perusahaan dalam mempertimbangkan keputusan untuk membayarkan besarnya dividen kas yang akan diberikan.

6. Hipotesis yang keenam (H6) menunjukkan bahwa "Firm Size memiliki pengaruh terhadap dividen kas"adalah tidak terbukti. Hasilnya diterangkan 
dengan besarnya Sig.t (nilai signifikansi t) adalah sebesar 0,742>0,05 atau 5\%(derajat kepercayaan). Sehingga dapat dikatakan bahwa variabel Firm Size tidak mempunyai pengaruh yang signifikan terhadap dividen kas. Hal ini disebabkan oleh keputusan manajemen perusahaan untuk mengalihkan dana untuk menginvestasikan kembali, ekspansi perusahaan dan kegiatan yang menggunakan pendanaan selain pendistribusian dividen kas.

\section{SIMPULAN DAN SARAN}

\subsection{Simpulan}

1. Return On Investment tidak mempunyai pengaruh terhadap dividen kas Dari hasil analisis dapat diketahui bahwa laba ternyata tidak digunakan untuk pembayaran dividen. Laba bersih perusahaan diinvestasikan kembali dalam aset yang produktif.

2. Quick Ratio berpengaruh terhadap dividen kas. Dengan demikian, Quick Ratio dapat dijadikan pertimbangan berinvestasi dalam mengharapkan dividen tunai.

3. Current Ratio tidak berpengaruh terhadap dividen kas. Manajemen perusahaan juga ingin mempertahankan tingkat likuiditas untuk memberikan perlindungan dan fleksibilitas keuangan terhadap ketidakpastian.

4. Debt to Total Asset berpengaruh terhadap dividen kas. Dengan demikian, Debt to Total Asset dapat dijadikan pertimbangan berinvestasi dalam mengharapkan dividen tunai.

5. Earning Per Share berpengaruh terhadap dividen kas. Dengan demikian, Debt to Total Asset dapat dijadikan pertimbangan berinvestasi dalam mengharapkan dividen tunai.

6. Firm Size tidak berpengaruh terhadap dividen kas. Hal ini disebabkan oleh keputusan manajemen perusahaan untuk mengalihkan dana untuk menginvestasikan kembali, ekspansi perusahaan dan kegiatan yang menggunakan pendanaan selain pendistribusian dividen kas.

7. Return On Investment, Quick Ratio, Current Ratio, Debt to Total Asset,Earning Per Share dan Firm Size bersama-sama mempunyai pengaruh terhadap dividen kas.

\subsection{Saran}

1. Bagi peneliti selanjutnya penelitian ini lebih baik menggunakan sampel dari penelitian yang memiliki area yang lebih luas/banyak lagi yakni dengan menambahkan tahun penelitian yang lebih lama dari penelitian ini serta memasukkan objek pada penelitian yang lebih luas dari area ini seperti membandingkan terhadap indeks KOMPAS100, Indeks27, Jakarta IslamicIndex. Sehingga data tersebut mempunyai area cakupan yang lebih luas guna dijadikan sampel untuk penelitian selanjutnya. Peneliti selanjutnya juga lebih baik menggunakan seluruh perusahaan yang terdaftar di Bursa Efek Indonesia sebagai sampel penelitian.

2. Bagi Investor akan sangat baik untuk mempertimbangkan berbagai hal yang sangat penting dalam melakukan pengambilan keputusan investasi yang akan dilakukannya, sehingga hal ini akan memberikan profit yang baik baginya..

3. Bagi pihak perusahaan untuk perusahaan Indeks LQ45 penelitian ini diharapkan akan dapat menjadi dasar dalam memutuskan keputusan perusahaan sehubungan terhadap pembayaran dividen kas kepada pemangku saham (investor).

\section{DAFTAR REFERENSI}

Amyas, Muhammad Arfan dan Hasan Basri. 2014. "Pengaruh Quick Ratio, earning per share, dan return on investment terhadap dividen kas". Jurnal Akuntansi ISSN 2302-0164. Magister Akuntansi Pascasarjana Universitas Syiah Kuala Banda Aceh. Pp. 1- 9.

Baridwan, Zaki. 2009. Intermediate Accounting. BFFE: Yogyakarta

Bidari, Wiwin Leony, Putu Kepramareni dan Ni Luh Gde Novitasari. 2018. "Pengaruh Laba Akuntansi, Earning Per Share dan Laba Tunai Terhadap Dividen Kas (Studi pada perusahaan manufaktur yang terdaftar di Bursa Efek Indonesia)". Jurnal Riset Akuntansi. Volume 8 No.1. Hal.75-85

Dewi, Dian Masita. 2016. "Pengaruh Likuiditas, Leverage, Ukuran Perusahaan Terhadap Kebijakan Dividen Tunai Dengan Profitabilitas Sebagai Variabel Intervening". Jurnal Bisnis dan Ekonomi, Hal. 12 - 19 Vol. 23, No. 1.

Fahmi, Irham. 2018. Analisis Laporan Keuangan. Bandung: Alfabeta

Ghozali, Imam. 2016. Aplikasi Analisis Multivariate dengan Program IBM SPSS 23. Semarang: Badan Penerbit Universitas Diponegoro.

Gloria Julianita Sendow, Grace B. Nangoi, Winston Pontoh. 2018. "Faktor - Faktor Yang Mempengaruhi Kebijakan Dividen Pada Perusahaan Manufaktur Yang Terdaftar Di Bursa Efek Indonesia Periode Tahun 2012-2016". Program Magister Akuntansi, Fakultas Ekonomi dan Bisnis Universitas Sam Ratulangi.

Hanafi, Mamduh M. dan Abdul Halim. 2018. Analisis Laporan Keuangan Edisi Kelima. Yogyakarta: UPP STIM YKPN.

Harahap, Sofjan Syafri. 2018. Analisis Kritis atas Laporan Keuangan. Jakarta: PT. Raja Grafindo Persada.

Hery. 2015. Analisis Laporan Keuangan. Jakarta: Bumi Aksara.

Husein, Umar. 2017. Metode Penelitian untuk Skripsi 
dan Tesis Bisnis. Jakarta : Raja-wali Pers.

Ifada, Luluk Muhimatul dan Nia Kusuma Dewi. 2014. "Pengaruh laba bersih, arus kas operasional, investment opportubity set dan firm size terhadap dividen kas". Jurnal Dinamika Akuntansi. Vol. 6 No. 2 September 2014. Pp. 177-190.

Irman, Mimelientesa, Gilang Satria Guinata dan Haugesti Diana. 2020. "Pengaruh Laba Bersih, Arus Kas Operasi dan Current Ratio terhadap Dividen Kas pada Perusahaan Aneka Industri yang terdaftar di Bursa Efek Indonesia". Jurnal Akuntansi, kewirausahaan dan Bisnis. Vol. 5 No. 1. Hal. 24-36.

Jumingan. 2011. Analisis Laporan Keuangan. Jakarta : Bumi Aksara

Kasmir. 2018. Analisis Laporan Keuangan. Bandung: Rajawali Pers.

Kieso, Donald E. Weygandt Jerry J. dan Terry D. Warfield. 2018. Akuntansi Intermediate. Edisi IFRS. Volume 2. Alih Bahasa: Emil Salim. Jakarta : Erlangga.

Muljono, D. 2015. Akuntansi dan Lembaga Keuangan Syariah. Yogyakarta: ANDI.

Munawir, S. 2014. Analisis Laporan Keuangan. Yogyakarta : Liberty.

Mutya, Anisa dan Vaya Juliana Dillak. 2018. "Analisis Faktor-Faktor yang Mempengaruhi Dividen Kas". Jurnal Aksara Public. Volume 2. No. 4 Hal 63-74.

Puspitawati, Lilis, Herlas Tia Dekayani 2014. "Pengaruh Laba Bersih dan Current Ratio Terhadap Dividen Kas Pada Perusahaan Pertambangan Yang Terdaftar di Bursa Efek Indonesia". Jurnal riset akuntansi, Universitas Komputer Indonesia.

Rahayu, Alia Sugeng , Mohammad Hari. 2016. "Pengaruh Current Ratio dan Quick Ratio terhadap Kebijakan Dividen Melalui Return On Equity Pada Perusahaan Manufaktur yang Terdaftar di BEI Tahun 2014". Jurnal Ekonomi Bisnis, Nomor 2. Fakultas Ekonomi Universitas Negeri Malang.

Ratnasari, Putu Sri Puspytha dan Ni Ketut Purnawati. 2019. "Pengaruh Profitabilitas, Likuiditas, Tingkat Pertumbuhan Perusahaan dan Leverage terhadap Kebijakan Dividen". E-Jurnal Ekonomi dan Bisnis. Vol. 8, No. 10, 2019. Hal : 6179-6198.

Sekaran, Uma dan Roger Bougie. 2017. Metode Penelitian untuk Bisnis : Pendekatan Pengembangan - Keahlian. Edisi 6. Buku 2. Jakarta Selatan : Salemba Empat.

Siregar, Cici Seliana. 2019. "Analisis Pengaruh Laba Akuntansi, Laba Tunai dan Likuiditas terhadap Dividen Kas Pada Perusahaan Manufaktur yang terdaftar di Bursa Efek Indonesia". Journal Economy and Currency Study. Volume 1 Issue 2.
Hal.27-34.

Stice, James D., Earl K. Stice, Fred Skousen. 2011. Intermediate Accounting. 17th Edition. USA. Cengage Learning.

Subramanyam, K. R. dan John J. Wild. 2013. Analisa Laporan Keuangan. Jakarta : Salemba Empat.

Wicaksono, Ramadhanu Adi ,Widya Susanti dan Mahsina. 2016. "Analisis pengaruh Cash Position, Debt to Total Asset dan Return On Asset terhadap Cash Dividend pada perusahaan LQ45 yang go public di Bursa Efek Indonesia". Jurnal Akuntansi UBHARA.Vol 3. Hal.110-120

Zuwita, Ega dan Deliza Enny. 2017. "Analisis pengaruh Likuiditas, Profitabilitas, Leverage, Arus Kas Bebas dan Dividen tahun sebelumnya terhadap Dividen Kas". Jurnal Akuntansi Trisakti. Vol.4 No.2. Hal.101-116. 